\title{
Assessing economic value of community forestry for sustainable rural development
}

\author{
Endah Saptutyningsih* , Taufiq Waisy Alqharni \\ Faculty of Economics and Business, Universitas Muhammadiyah Yogyakarta, Indonesia
}

\begin{abstract}
Community forestry contributes to the rural economy in a variety of ways: directly as a consumer of land and services to convert biological and other inputs into a variety of outputs; indirectly through its linkages with upstream producers and downstream processing sectors; and indirectly through the respending in rural areas of portions of income generated from forestry and related industries. through the provision of non-market benefits; and a pleasant living atmosphere for many people. This study aims to estimate the economic value of community forests in Pajangan, Bantul district. The benefits of community forests can be direct use values and indirect use values. The benefits of Pajangan community forests are estimated using the Total Economic Value (TEV) method. The result shows that TEV of IDR 70,298,307,526 per year, consisting of direct use value of IDR 9,344,000,000 per year, the indirect use value of IDR $35,274,178,836$ per year. It is critical to provide economic incentives for communities to participate in sustainable rural development such as ensuring that the full economic value of forests is recognized and reflected in both economic and forestry decision-making, with a focus on economic costs and benefits that accrue at the community level.
\end{abstract}

\section{Introduction}

The steady decline of forest resources was caused by rising human and animal populations, as well as the consequences of government land registration regulations [1]. In the late 1970s, community forestry was established in recognition of the need of citizen participation in natural resource management. This technique was developed at a period when forest development plans from the 1950s and 1960s were criticized for ignoring rural development and failing to fulfill the basic requirements of the rural poor [2]. Many research findings in various countries, particularly developing ones, have demonstrated people's reliance on forests' existence, particularly in poorer areas such as Nepal's Koshi Tappu Wildlife Reserve [3], Indonesia [4,5], Kenya [6], and elsewhere. After more than two decades of implementation, the program is now widely regarded as the most advanced and innovative

\footnotetext{
* Corresponding author: endahsaptuty@umy.ac.id
} 
model for participatory natural resource management anywhere on the planet [7]. Community forestry is the control and management of forest resources by rural people who use them primarily for domestic needs and as an integrated element of their farming systems. Several studies have found that impoverished people are excluded from community forestry benefits [7], because decision-making forums are dominated by elites [8, 9]. On the other hand, it has been cited in other research as having a favorable impact on poverty reduction [10-12].

Community forest is a form of forest that is divided into private forest. Community forests are described as forests that grow on land that has been encumbered with property rights, implying that they are not grown on state land [13]. In practice, community forest is carried out by people who reside or are near the community forest area itself, sometimes known as forest village communities. A community forest, according to another definition, is a growing forest on privately owned land that is encumbered with rights to ownership of the land, including ownership rights, with a minimum area of 0.25 ha and a closure of timber and other plants of more than $50 \%$ [14].

The community forestry plan applied agroforestry approaches that are considered as contributing to food security to provide answers to sustainable forest management based on sustainable economic, ecological, and social principles [15-19], nutrition [20-22], Improvements in soil quality and long-term production systems [23], microclimate alteration, food, medication, animal feed $[24,25]$. Community forests are an integral element of the lives of forest village communities [26]. The pattern of forest village communities' relationship with community forests is highly diversified and differs from one place to the next, as evidenced by the state of soil fertility, community culture, and local stakeholder policies or any parties with control over the establishment of communal forests However, it can be stated that community forests play a vital role in the lives of forest village communities, both economically, socially, and in terms of environmental circumstances.

The importance of community forests in the lives of forest village communities can be seen in their potential distribution, such as the potential distribution of community forests in Java-Madura, which is estimated to be $2,585,014.06$ ha, with an estimated volume of community forest wood of 74,763,602.06 $\mathrm{m} 3$ or $28.92 \mathrm{~m} 3 /$ ha [26] implying that nearly half of the total area of community forests is in this region. This is due to the fact that community woods on Java-Madura Island have been known for a long time and are passed down from generation to generation, and they differ from community forests elsewhere in terms of cultivation and ownership status. Because the opportunity cost of expanding community forests outside of Java is larger than that of plantation crops such as rubber and oil palm, the management and development of community forests in Java is more intensive and better.

Researchers have conducted numerous economic assessment studies, including ones on the economic value of non-timber forest products in the Kapuas-Kahayan protected forest [27], as well as the economic value of fruit, fuel wood, and water in protected forests. Wosi Rendani, West Papua, is another example [28], Economic value of ecosystem services in the Mazandaran Forest Reserve [29], overall economic value of agroforestry in the Krueng Aceh watershed area [30], and so on. Economic assessment studies can be utilized to demonstrate that conservation can result in measurable economic advantages for the community [31]. Furthermore, economic assessments of environmental resources are an important theoretical tool for making decisions about the distribution of scarce natural resources [32]. If natural resources and the environment have little economic value, they might be exploited by the community since they are undervalued or even considered useless [33]. In order to solve economic and environmental challenges, it's critical to determine the economic value of food crops in this community forest region. However, a study focusing on the economic value of community forest especially in Indonesia remains inconclusive. 
To fill in this knowledge gap, this study determines the direct and indirect usage values of the Pajangan District Community Forest in Bantul Regency. This study also assesses the value of choice, the community's willingness to pay (WTP), and the total economic value (TEV) of Community forest. We surveyed the communities in Pajangan District, Bantul Regency, one of which is the center of community forest development is Bantul Regency. There are 3 villages include 45 farmer groups,

\section{Methods}

\subsection{Study site}

The research was conducted on a community forest located in Pajangan District, Bantul Regency, Yogyakarta Special Region (DIY). The location selection was carried out because it was assessed that the existence of a community forest area (HR) in Pajangan District, Bantul Regency was very beneficial for the lives of village communities around the forest, so it is hoped that after an economic valuation is carried out, the decision makers can make appropriate policies for the purpose of preserving the area. community forest in Pajangan District, Bantul Regency.

\subsection{Data and sampling}

Data collection in this study was carried out in several ways, including: Literature study to obtain secondary data about the characteristics of community forests and other matters related to the research objectives, Observation, by observing and recording observations in the field, and interviews using questionnaire to obtain data that includes data on gender, age, status, education level, occupation, income, distance between residence and forest land, and respondents' willingness to pay (WTP) so that environmental services in Pajangan District, Bantul are maintained.

The sample in this study was taken from the total population of the study, namely the number of members of UMHR Wono Lestari Bantul in 3 villages is 45 farmer groups, and the total members who have registered community forest land are three thousand five hundred and sixty six $(3,566)$ families. With the use of a sample, researchers can obtain data that can describe the state of the population at an affordable cost and a more efficient period of time [34]. Sampling was done by purposive sampling (sampling purpose). To determine the number of samples in the study used the Slovin method [35]. By taking the error rate (d) $10 \%$ and the total population (N) 3,566; then the number of samples (n) is 97 people.

\subsection{Data analysis}

\subsubsection{Total Economic Value of Community Forest}

The total economic value (NET) is the total (result) of the total use value and non-use value of community forests.

$$
T E V=D U V+N D V+O V+B V
$$

where TEV is total economic value, DUV is direct use value, NDV is non-direct use value, $\mathrm{OV}$ is option value, and $\mathrm{BV}$ is bequest value. 


\subsubsection{Use Value of Log Wood}

The value of the logs is calculated based on the prices prevailing at the research site. The estimated value of logs (NKL) is teak, acacia, and mahogany, which can be calculated using the following equation:

$$
N K L i=E i x H K L i
$$

where NKLi is total value of i-type logs (IDR/year), Ei is strict volume of sustainable cutting of $i$-type wood (m3/year), HKLi is price of logs per cubic type-i (IDR/m3), i is type of wood (Teak, Acacia, Mahogany).

Table 1. Determination of economic value and research methods

\begin{tabular}{|c|l|c|}
\hline No. & \multicolumn{1}{|c|}{ Economic Value } & \multicolumn{1}{c|}{ Methods } \\
\hline 1. & $\begin{array}{l}\text { Use Value } \\
\text { Direct Use Value (DUV) } \\
\text { a. Log Wood Value } \\
\text { b. Firewood Value }\end{array}$ & $\begin{array}{l}\text { Valuation Based on Market Price } \\
\text { Valuation Based on Market Price }\end{array}$ \\
\cline { 2 - 3 } & $\begin{array}{l}\text { Indirect Use Value (NDV) } \\
\text { a. Carbon Absorbent Value } \\
\text { b. Spring Value }\end{array}$ & $\begin{array}{l}\text { Valuation Based on Market Price } \\
\text { Valuation Based on Market Price }\end{array}$ \\
\hline 2. & $\begin{array}{l}\text { Preferred Value (OV) } \\
\text { Value of Biodiversity }\end{array}$ & Replacement Cost Approach \\
\hline 3. & $\begin{array}{l}\text { Non-Use Value } \\
\text { Inheritance Value (BV) }\end{array}$ & Contingent Valuation Method \\
\hline
\end{tabular}

\subsubsection{Firewood Value}

The value of firewood is calculated by direct approach (market price). To calculate the economic value of firewood, the price of firewood prevailing at the research site is used, then the price is multiplied by the amount of firewood needed or sales of firewood by forest farmers obtained from community forests in Pajangan District, Bantul Regency. The value of firewood can be calculated using the following equation:

$$
N K B=J K B \quad x H K B
$$

where NKB is economic value of firewood (IDR/year), JKB is total sales of firewood (cars/year), HKB is applicable price of firewood (IDR/car).

\subsubsection{Carbon Absorbent Value}

Determination of the value of carbon sinks at the study site using a benefit transfer approach. According to Mugiono [26], the estimated carbon content of HR wood in Java-Madura is $40,724,689.34$ tons, or 15.75 tons/ha, so the carbon sink value can be calculated by the following equation:

$$
N P K=C O x P C x L A
$$

where NPK is total value of carbon sinks (IDR/year), $\mathrm{CO}$ is carbon content in wood/ha (15.75 tons/ha), PC is carbon price (US \$12/ton), LA is area of study (ha). 


\subsubsection{Spring Value}

The economic value of the springs at the research site, a direct approach is used, namely based on the applicable tariffs at the research site with the following mathematical equation:

$$
N M A=n K K x \text { USE } x \text { Pair }
$$

where NMA is spring economic value (IDR/year), $\mathrm{nKK}$ is number of household heads who use the springs, USE is average water use per household (m3/year), Pair is the prevailing water price in PDAM Bantul Regency (IDR/m3)

\subsubsection{Value of Biodiversity}

Calculation of the value of biodiversity is calculated based on the benefit transfer approach. The value of biodiversity benefits for secondary forest is US $\$ 32.5 /$ ha/year [36], then the value of biodiversity can be calculated by the equation below:

$$
N K H=N H S x L A
$$

where NKH is total value of biodiversity (IDR/year), NHS is secondary forest biodiversity value (IDR/ha), LA is area of study (ha).

\subsubsection{Inheritance Value}

The steps in conducting research to obtain inheritance values are to determine the value of the community's willingness to pay (WTP) for the preservation of community forests in Pajangan district Bantul Regency, as follows:

\subsubsection{Creating a Hypothetical Market}

The hypothetical market was formed on the basis of the needs of forest village communities for the existence of community forests from the benefits of environmental services from community forests as a provider of clean air and water absorption benefits. With Scenarios like the following:

"One day the quality of the environment will decline due to various reasons, for example using forest products that are not environmentally friendly and limited funds to maintain good environmental quality. If the benefits of environmental services from the community forest area of Pajangan District are to remain sustainable and last so that they can be felt as long as possible, it is necessary to have conservation efforts from the surrounding community, such as: delayed logging, selective slashing, planting a certain number of seeds for each tree felling, and so on"

\subsubsection{Get an offer for the amount of WTP value}

The technique used in obtaining the value of the offer in this study is to ask whether the respondent is willing to pay a certain amount of money or not, and state the amount that is ready to be spent with the money used to obtain environmental quality improvements through payments for environmental services. 


\subsubsection{Estimating the Average Value of WTP}

WTP can be estimated by doing the average value, which is the sum of the total WTP values divided by the number of respondents. The estimated average WTP is calculated by the formula:

$$
E W T P=\sum_{i=0}^{n} W i P f i
$$

where EWTP is estimated mean WTP, Wi is $\mathrm{i}$-th WTP value, Pfi is relative frequency, $\mathrm{n}$ is number of respondents, $i$ is the $i$-th respondent who is willing to pay.

\subsubsection{Sum Data}

Data summation is a process where the median supply value is converted to the total population in question. After estimating the mean WTP value, the WTP value is then added up to obtain the total WTP value which is assumed to be the inheritance value.

\subsection{Pajangan Community Forest Area}

One of the provinces that is quite serious in developing the potential of community forests both in terms of management and cultivation of community forests is the province of the Special Region of Yogyakarta. In the Special Province of Yogyakarta, community forests are developed in 5 districts, one of which is the center of community forest development is Bantul Regency. Protected areas formed by the Regional Government of Bantul Regency are spread over 17 sub-districts, one of which is Pajangan District.

As a form of realization of the existing protected areas in Pajangan Sub-district is to continue to increase the quantity and quality of community forests in Pajangan District, which are spread over 3 villages in Pajangan District, namely: Sendangsari Village, Triwidadi Village, and Guwosari Village. With the large potential of community forests in three villages in Pajangan District, the Wono Lestari Bantul Community Forest Management Unit (UMHR) was established as a forum for existing farmer groups.

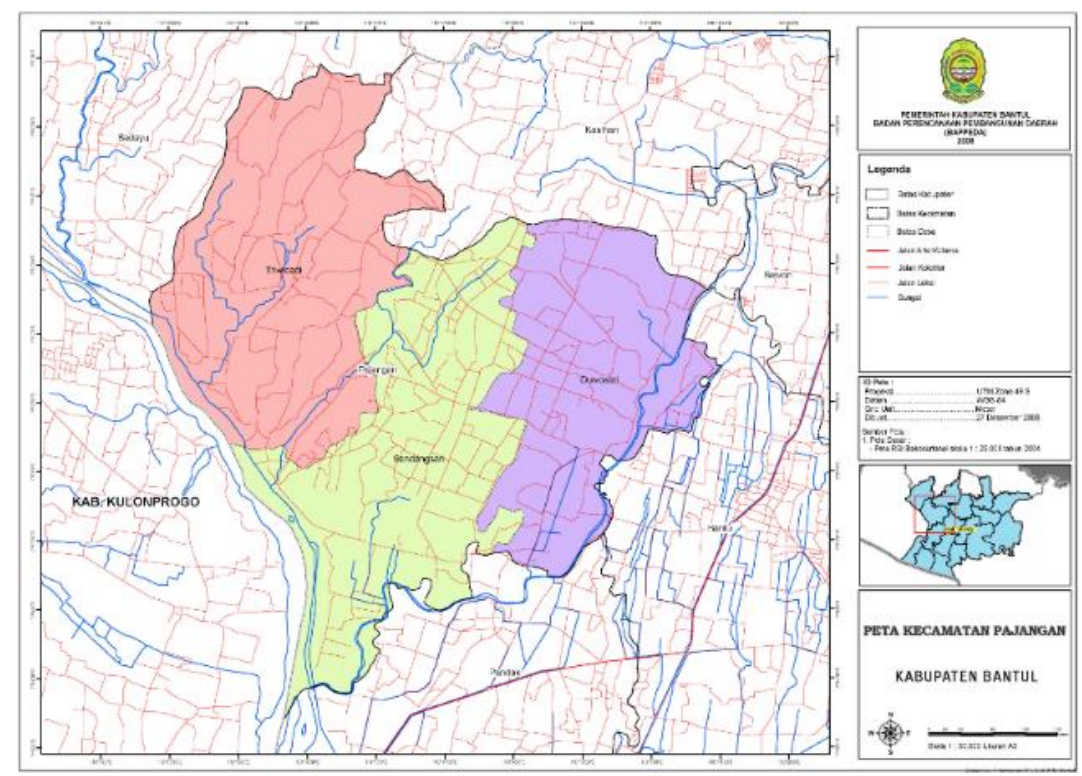

Fig 1. Pajangan district map 
The establishment of UMHR Wono Lestari Bantul was motivated by the Minister of Forestry Regulation No. 38 of 2009 (P.38/Menhut-II/2011) concerning standards and guidelines for evaluating the performance of sustainable production forest management and timber legality verification. UMHR Wono Lestari Bantul was established on July 10, 2012, with an initial area of 1,027.604 ha located and spread over 34 hamlets in Sendangsari Village and Triwidadi Village. On October 1, 2014, farmer groups in Guwosari Village then legally joined as members of UMHR Wono Lestari Bantul which was also added to 4 hamlets in Triwidadi Village and 2 hamlets in Sendangsari Village that were not yet incorporated into UMHR Wono Lestari Bantul [37].

The number of farmer groups under the UMHR Wono Lestari Bantul working area is 45 farmer groups spread over 3 villages (see Table 1). The number of farmer groups in Sendangsari Village and Triwidadi Village is the same, namely 17 groups, then in Guwosari Village there are 11 groups.

Table 1. UMHR Wono Lestari Working Area Bantul

\begin{tabular}{|c|l|c|c|c|}
\hline No. & Location & $\begin{array}{c}\text { Number } \\
\text { of } \\
\text { Groups }\end{array}$ & $\begin{array}{c}\text { Community } \\
\text { Forest Area } \\
\text { (ha) }\end{array}$ & $\begin{array}{c}\text { Number of } \\
\text { Members } \\
\text { (Hh) }\end{array}$ \\
\hline 1 & Sendangsari Village & 17 & 349.29 & 1,453 \\
\hline 2 & Triwidadi Village & 17 & 487.26 & 1,636 \\
\hline 3 & Guwosari Village & 11 & 106.02 & 474 \\
\hline \multicolumn{2}{|c|}{ Total } & 45 & 939.59 & 3,566 \\
\hline
\end{tabular}

Source: [37]

The total area of community forest (HR) in these three villages is 939.59 ha. Sendangsari Village 345.29 ha, Triwidadi Village 487.26 ha, and Guwosari Village 106.02 ha. Then the number of members from each village is 1,453 Sendangsari Village, 1,636 Triwidadi Village, and 474 Guwosari Village. The total number of members is 3,566 members.

Table 2. Total Tree Stand Potential in Each Village

\begin{tabular}{|c|c|c|c|}
\hline Location & $\begin{array}{c}\text { Total } \\
\text { Volume }\end{array}$ & $\begin{array}{c}\text { Total } \\
\text { Volume } \mathbf{x} 2 \\
\left(\mathbf{m}^{\mathbf{3}}\right)\end{array}$ & $\begin{array}{c}\text { Total Etat } \\
\mathbf{p e r} \text { Tahun } \\
\left(\mathbf{m}^{\mathbf{3}}\right)\end{array}$ \\
\hline Sendangsari Village & 580.360 & $1,160.721$ & 165.817 \\
\hline Triwidadi Village & $1,082.620$ & $2,165.238$ & 309.319 \\
\hline Guwosari Village & 335.124 & $6,70.248$ & 95.749 \\
\hline
\end{tabular}

Source: [37]

The total potential in the three existing villages differs from one another (See Table 2). The total stand volume potential with the largest number is in Sendangsari Village, which is 580,360 with a total area of 165,817 , while Guwosari Village is 335,124 with 95,749 per year, and the smallest total potential volume of stands is Triwidadi Village, which is 1082.620 with an annual area of 309.319. The total standing potential in these three villages is dominated by three main types of woody plants, namely Teak, Mahogany, and Acacia.

The Wono Lestari Community Forest Management Unit (UMHR) of Wono Lestari Bantul was established as a forum for farmer groups in Bantul Regency on July 10, 2012, with an initial area of 786.54 ha, spread over 34 hamlets in Sendangsari Village and Triwidadi Village. The existence of the Minister of Forestry Regulation No. 38 of 2009 (P.38/Menhut-II/2011) concerning standards and guidelines for assessing the performance of sustainable production forest management and timber legality verification, initiates community forest owners to create a legal entity that can be used as a forum for community forest owners in Bantul Regency, this is the background behind the establishment of 
UMHR Wono Lestari Bantul. In 2013, precisely in March, Wono Lestari Bantul UMHR was declared to have passed the timber legality certification with a management area of 786.54 ha spread across Sendangsari and Triwidadi villages. Then in 2014, through the Wono Lestari UMHR Member Conference, the farmer group in Guwosari Village became a member of Wono Lestari UMHR so that the total area of management increased to 959,305 ha.

Table 3. History of Community Forest Management

\begin{tabular}{|c|l|l|}
\hline Year & \multicolumn{1}{|c|}{ Field Condition } & \multicolumn{1}{c|}{ Important Events } \\
\hline 1965 & $\begin{array}{l}\text { District of Pajangan is dry, } \\
\text { barren, and arid }\end{array}$ & $\begin{array}{l}\text { There was no activity because that year } \\
\text { there was political upheaval in Indonesia }\end{array}$ \\
\hline $1965-1970$ & $\begin{array}{l}\text { Residents are starting to } \\
\text { pay attention to their own } \\
\text { land with land maintenance }\end{array}$ & $\begin{array}{l}\text { 1. Political power in the country was } \\
\text { under the new order and all sectors } \\
\text { received attention, including dry land } \\
\text { 2. The government provides assistance } \\
\text { for teak, acacia, mahogany, melinjo and } \\
\text { mango seeds for reforestation }\end{array}$ \\
\hline $1970-1975$ & & $\begin{array}{l}\text { A reforestation group has been formed } \\
\text { led by Bpk. Yitno Sumarto is a nursery } \\
\text { for melinjo, acacia, and milk guava }\end{array}$ \\
\hline $1975-1980$ & $\begin{array}{l}\text { Well maintained land but } \\
\text { only certain plants can live }\end{array}$ & $\begin{array}{l}\text { 1. Dropping seeds from the government } \\
\text { 2. The labor-intensive program opens an } \\
\text { asphalt road from the Dwiwindu field } \\
\text { through the hills in the Pajangan area } \\
\text { 3. Limestone mining in hilly areas } \\
\text { 4. The community planted the land with } \\
\text { agricultural crops but it didn't work and } \\
\text { then replaced it with perennials }\end{array}$ \\
& & $\begin{array}{l}\text { 1. The hard plants planted are starting to } \\
\text { sell well in the market so that the } \\
\text { community's desire to plant is greater } \\
\text { 2. Many programs lead to the } \\
\text { development of community forests from } \\
\text { the government }\end{array}$ \\
\hline $1980-1990$ & $\begin{array}{l}\text { Land condition has been } \\
\text { improved }\end{array}$ & $\begin{array}{l}\text { The price of wood is getting higher and } \\
\text { higher }\end{array}$ \\
\hline $1990-$ now & Maintenance & \\
& &
\end{tabular}

Source: [37]

Table 4. Area of Community Forest

\begin{tabular}{|c|c|c|}
\hline No & Location & Area (ha) \\
\hline 1. & Sendangsari Village & 366,027 \\
\hline 2. & Triwidadi Village & 487,256 \\
\hline 3. & Guwosari Village & 106,022 \\
\hline \multicolumn{2}{|c|}{ Jumlah } & $\mathbf{9 5 9 , 3 0 5}$ \\
\hline
\end{tabular}

Source: [37]

The area of community forest in Pajangan District is based on 3 existing villages (see Table 4). First, the community forest area in Sendangsari Village is 366.027 ha or $58 \%$ of the total community forest area in Wono Lestari UMHR, Bantul, then community forest in Triwidadi Village is 487.256 ha or $27 \%$ of the total community forest area in UMHR Wono Lestari Bantul, and the last community forest in Guwosari Village is 106.0022 ha or $20 \%$ of the total area of community forest in UMHR Wono Lestari Bantul. So the total area of community forest in Pajangan District is 959.305 ha or equal to $3 \%$ of the total area of Pajangan District, Bantul Regency. 


\section{Results and Discussion}

\subsection{Direct Use Value (Direct Use)}

One of the direct benefits from the community forest area of Pajangan Subdistrict is the result of logs. Communities who own forest land can directly sell logs to buyers, to collectors or to sell through existing farmer groups at prices that are valid and of course agreed upon. However, so far, in practice, there are still many people who carry out logging in need so that the felling of logs is not properly scheduled and the community also does not get the maximum price for sales made in this way. The potential of logs as direct benefits from community forests in Pajangan District is divided into three types, namely, teak wood, acacia wood, and mahogany wood.

Table 5. List of Timber Prices in Pajangan District

\begin{tabular}{|c|c|c|c|}
\hline $\begin{array}{c}\text { Diameter } \\
(\mathbf{c m})\end{array}$ & Teak & Acacia & Mahogany \\
\hline $7-16$ & IDR $1,100,000$ & IDR 800,000 & IDR600,000 \\
\hline $16-21$ & IDR2,200,000 & IDR $1,800,000$ & IDR1,200,000 \\
\hline $22-28$ & IDR3,500,000 & IDR3,000,000 & IDR2,000,000 \\
\hline$>30$ & IDR4,500,000 & IDR3,500,000 & IDR2,500,000 \\
\hline
\end{tabular}

Source: [37]

\subsubsection{Teak wood value}

Based on the results of the study, the most teak trees in the community forest area of Pajangan District were in the MU category with a diameter of $16-20 \mathrm{~cm}$. The prevailing price at the research site for UP category teak trees with a diameter of $16-20 \mathrm{~cm}$ is IDR $2,200,000.00 / \mathrm{m} 3$. The annual sustainable cutting volume for teak is $2000 \mathrm{~m} 3 /$ year. Assuming that every year the three types of logs, namely teak, acacia, and mahogany that grow in the community forest of Pajangan District, are able to reach the maximum value of sustainable logging, the economic value of teak can be calculated as follows:

NKLjati $=$ HKLjati $x$ Ejati

NKLjati $=$ IDR 2,200,000.00/m3 x 2,000 m3/year

NKLjati $=$ IDR 4,400,000,000.00/year

Where NKLjati is value of teak logs (IDR/year), HKLjati is he price of teak logs (IDR/m3), Ejati isStrictly sustainable harvest volume per year for teak species (m3/year).

\subsubsection{Acacia wood value}

Based on the results of interviews, the most acacia trees in the community forest area of Pajangan District were in the MU category with a diameter of $16-20 \mathrm{~cm}$. The prevailing price at the research site for acacia trees in the MU category with a diameter of $16-20 \mathrm{~cm}$ is IDR $1,80,000.00 / \mathrm{m} 3$, with an annual sustainable cutting volume of $1600 \mathrm{~m} 3 /$ year. Assuming that every year the three types of logs, namely teak, acacia, and mahogany that grow in the community forest of Pajangan District, are able to achieve the maximum value from sustainable logging, the economic value of acacia wood can be calculated as follows:

NKLakasia $=$ HKLakasia $\mathrm{x}$ Eakasia

NKLakasia $=$ IDR $1,800,000.00 / \mathrm{m} 3 \times 1600 \mathrm{~m} 3 /$ year

NKLakasia $=$ IDR2,880,000,000.00/year 
where NKLakasia is value of acacia logs (IDR/year), HKLakasia is price of acacia logs $(\mathrm{IDR} / \mathrm{m} 3)$, Eacacia is strictly sustainable harvest volume per year for acacia species (m3/year)

\subsubsection{Mahogany wood value.}

Based on the results of interviews, mahogany in the community forest area of Pajangan District is mostly in the MU category with a diameter of $16-20 \mathrm{~cm}$. the prevailing price at the research site for mahogany wood category UP with a diameter of $16-20 \mathrm{~cm}$ is IDR $1,200,000.00 / \mathrm{m} 3$, and the annual sustainable cutting volume is $1600 \mathrm{~m} 3 /$ year. Assuming that every year the three types of logs, namely teak, acacia, and mahogany that grow in the community forest of Pajangan District, are able to achieve the maximum value from sustainable logging, the economic value of mahogany can be calculated as follows:

NKL mahogany $=$ HKL acacia $x$ E acacia

NKL mahogany $=$ IDR 1,200,000.00/m3 x $1600 \mathrm{~m} 3 /$ year

NKL mahogany $=$ IDR1,920,000,000.00/year

where NKL mahogany is the value of acacia logs (IDR/year), HKL mahogany is the price of acacia $\operatorname{logs}(\mathrm{IDR} / \mathrm{m} 3)$, Emahogany is etat annual sustainable cutting volume of acacia species (m3/year).

\subsubsection{The economic value of logs}

Based on the calculation of the economic value of wood from each type, namely: teak, acacia, and mahogany, it can be calculated the potential total economic value of the logs contained in the community forest area of Pajangan District are:

NKLtotal $=$ NKLjati + NKLakasia + NKLmahogany

NKLtotal $=$ IDR 4,400,000,000.00+ IDR 2,880,000,000.00 + IDR 1,920,000,000.00

NKLtotal $=$ IDR 9,200,000,000.00/year

Table 6. Economic Value of Log Wood

\begin{tabular}{|l|c|}
\hline Wood Type & Economic Value (IDR/year) \\
\hline Teak & IDR4,400,000,000 \\
\hline Acacia & IDR2, $880,000,000$ \\
\hline Mahogany & IDR $1,920,000,000$ \\
\hline
\end{tabular}

The previous research showed that the economic value of timber from the Bukit Soeharto Grand Forest Park, East Kalimantan was IDR 42,954,916.760.00/year or 62\% greater than the economic value of wood from community forests in Pajangan District [38]. The difference in the economic value of wood is due to differences in the amount and type of wood calculated, the diameter of the growing wood that dominates, the prevailing wood price, and the logging rate, as well as the area of the study where the Bukit Soeharto Grand Forest Park has an area of 61,850 ha.

\subsubsection{Economic value of firewood}

Community forests in Pajangan District have direct benefits that can also be estimated for their economic value apart from logs, namely firewood. Dry trunks and twigs from trees that grow in the community forest area of Pajangan District can be used for firewood as fuel. By the community, firewood is sold to batik industrial factories in Pajangan District and other areas, therefore firewood has a selling value for the community so that its economic value can be estimated. To obtain the economic value of firewood, the method 
used in this research is the market price approach. In practice, the firewood sold by the community is calculated in units of a Colt car, especially the Mistsubisi L300 or something like that. No one has ever researched or calculated the economic potential of firewood produced by people's forests in Pajangan District directly, and the calculation of the economic potential of firewood is as follows:

$$
\begin{aligned}
& \mathrm{NKB}=\mathrm{JKB} \times \mathrm{HKB} \\
& \mathrm{NKB}=360 \text { cars/year } \times \text { IDR } 400,000.00 / \text { car } \\
& \mathrm{NKB}=\mathrm{IDR} 144,000,000.00 / \text { year }
\end{aligned}
$$

where NKB is the value of firewood (IDR/year), JKB is the amount of firewood needed (car/year), HKB is the price of firewood (IDR/car).

The previous study shows the value of firewood from the community forest of Giriwoyo District, Wonogiri at IDR 1,758,960,000.00/year [39]. This value is much greater than the value of firewood from the community forest of Pajangan District, while the difference in this value is due to the difference in the price of firewood, namely in Firdaus' (2013) research, the price of wood is calculated based on units of bundle with a value of IDR $7,500.00 /$ bunch. Then the use of firewood is carried out by households (assuming preprosperous households).

\subsection{Indirect Use Value}

\subsubsection{Carbon sink value}

Plants that are or grow in forest areas naturally carry out photosynthesis to produce food for the plants themselves, so this makes the forest has a function as a carbon sink. The process of photosynthesis is very useful for other living things, especially humans, because in the process of photosynthesis, plants will absorb carbon gas which of course is not good for human health and can be detrimental to human health. The ability of a forest to perform its function as a carbon sink depends on the volume of biomass in the forest. To be able to calculate the value of carbon sinks in the community forest of Pajangan District, the benefit transfer method is used. It is estimated that the carbon content of community forest wood in Java-Madura is $40,724,689.34$ tons or 15.75 tons/ha [26]. The total area of community forest in Pajangan District is 959,305 ha, and the international market carbon price is on average US\$12/ton [40] with an exchange rate of US\$1 worth IDR14,046.50.00 (as of December 2019). With these data, the value of carbon sinks for community forests in Pajangan District is:

$$
\begin{aligned}
& \mathrm{NPK}=\mathrm{CO} \times \mathrm{PC} \times \mathrm{LA} \\
& \mathrm{NPK}=15,75 \text { ton/ha } \times \text { IDR } 168,558,00 / \text { ton } \times 959,305 \text { ha } \\
& \mathrm{NPK}=\mathrm{IDR} 2,546,751,882,00 / \text { year }
\end{aligned}
$$

where NPK is Carbon sink value (IDR/year), CO is Carbon content in wood (tonnes/ha), $\mathrm{PC}$ is Carbon price (IDR/ton), LA is Area of community forest (ha).

Different values are shown by the results of research [38] in the Bukit Soeharto Community Forest Park, East Kalimantan, with a value of IDR 691,097,940,000/year. As for the difference in value, which shows the carbon sink value of Bukit Soeharto Forest Park, East Kalimantan has a greater value than the value of community forest in Pajangan District because the area calculated to obtain a carbon sink value is 52030 ha while the community forest in Pajangan District is 959.305 ha. 


\subsubsection{The economic value of springs}

Forests naturally have the benefit of a hydrological function, namely through the roots of trees or plants in the forest that can regulate the flow of groundwater. The hydrological function of the forest produces several springs located in several springs in the area around the community forest of Pajangan District. The sustainability of this spring is strongly influenced by the sustainability of the people's forest in Pajangan District. Based on the results of interviews with residents, even when there was a long dry season, the residents of Pajangan Sub-district never felt a shortage of water to meet their living needs, livestock needs and irrigation for water.

Table 7. The clarity of Springs

\begin{tabular}{|c|c|c|}
\hline Spring Name & Location & Clarity \\
\hline Tuk Demen & Triwidadi & clear \\
\hline Tuk Butuh & Triwidadi & clear \\
\hline Tuk Kalicandi & Sendangsari & clear \\
\hline Tuk Kunden & Sendangsari & clear \\
\hline Tuk Beji & Sendangsari & clear \\
\hline Tuk Sendang & Sendangsari & clear \\
\hline Tuk Kedung Bunder & Sendangsari & clear \\
\hline
\end{tabular}

Source: [37]

Based on data obtained from PDAM Bantul Regency, the average water use per head of household in Pajangan District is $29.5 \mathrm{~m} 3$ /month, where the number of households in Pajangan District is 9,792 households (Pajangan District Government, 2013). Assuming all houses in Pajangan District are classified as A3 Type A3 houses, then according to the tariff list issued by PDM Bantul Regency, the amount to be paid per household with consumption > $20 \mathrm{~m} 3 /$ month is IDR $6,300.00 / \mathrm{m} 3$. Based on the tariff, the economic value of the community forest spring in Pajangan District is:

$$
\begin{aligned}
& \text { NMA }=\text { nKK } \times \text { USE } \times \text { Pair } \\
& \text { NMA }=9,792 \times 354 \mathrm{~m} 3 / \text { year } \times \text { IDR6,300.00/m3 } \\
& \text { NMA }=\text { IDR21,838,1 18,400.00/year }
\end{aligned}
$$

where NMA is economic value of the spring (IDR/year), nKK is number of households using the spring, USE is average water use per household (m3/year), Pair is tariff applicable in PDAM Bantul Regency (IDR/m3 )

\subsection{Option Value (OV)}

The value of community forest choice in Pajangan District is estimated using the benefit transfer method. This method can be done by calculating the biodiversity value of the people's forest in Pajangan District. The value of biodiversity benefits for secondary forest is US \$ 32.5/ha/year if the existence of the forest is ecologically important and maintained [36]. This value is the value in 1993, with an inflation rate of $5.57 \%$. So the value of the biodiversity benefits of the people's forest in Pajangan District is currently US \$ 96.1/ha/year. The value is obtained by multiplying the above value by the total area of the community forest in Pajangan District, which is 959.305 ha. With an exchange rate of US\$1 = IDR14,050.00 (December 2019). So it can be assessed that the biodiversity of the people's forest in Pajangan District is IDR1,295,258,408.00/year.

In a previous study [41] the value of biodiversity from the mangrove forest of Margasari Village, Maringgai, East Lampung is IDR103,425,000.00/year. This value is much smaller than the value of biodiversity in community forests in Pajangan District, this is because the 
biodiversity value of mangrove forests is only US \$ 15 per hectare / year, and also the rupiah exchange rate in 2013 which is worth US \$ 1 worth IDR 9850.00 .

\subsection{Non-Use Value}

The value of community forest heritage in Pajangan District is estimated using the Willingness To Pay (WTP) analysis approach. Willingness To Pay (WTP) is an analysis carried out by calculating how much people want to spend money to pay for environmental services from HR of Pajangan District so that their sustainability is maintained for future generations after them (current society).

This PAP approach was carried out by asking the willingness of 97 respondents who live around community forests who are also members of the Wono Lestari UMHR Bantul to fill out the research questionnaire. Respondents were asked for their opinion on their willingness to make payments or spend money in order to maintain the environmental services function of the Pajangan District community forest so that its sustainability is maintained. The steps taken to obtain the bequest value of the community forest of Pajangan District are as follows:

\subsubsection{Create a hypothetical market}

The hypothetical market was formed on the basis of the needs of forest village communities for the existence of community forests from the benefits of environmental services from community forests as a provider of clean air and water absorption benefits. Furthermore, the hypothetical market is offered in the form of the following scenarios:

\subsubsection{Get the amount of the WTP value offer}

Based on the results of the interviews, of the total number of respondents being interviewed as many as 97 people, there were 6 respondents who were not willing to pay for environmental services from the Pajangan District private forest on the grounds that they did not have extra money to pay for environmental services obtained from community forests. As many as 91 respondents are willing to pay for environmental services, they are aware of the importance of forest functions for life and feel directly the benefits of environmental services in this case forests because most of them live very close to the forest. With what the respondents feel, they also have the desire that the benefits of the environmental service function of HR can also be felt by future generations and must be passed on.

Table 8. Distribution of Respondents' WTP Value

\begin{tabular}{|c|c|c|c|}
\hline $\begin{array}{c}\text { WTP } \\
\text { (IDR/bulan) }\end{array}$ & \multirow{2}{*}{$\begin{array}{c}\begin{array}{c}\text { Number of } \\
\text { Respondents }\end{array} \\
6\end{array}$} & \multicolumn{2}{|c|}{$\begin{array}{l}\text { Total WTP } \\
\text { (IDR/bulan) }\end{array}$} \\
\hline $\begin{array}{ll}\text { IDR } & 0.00\end{array}$ & & IDR & 0.00 \\
\hline IDR 2,000 & 2 & IDR & 4,000 \\
\hline IDR 3,000 & 1 & IDR & 3,000 \\
\hline IDR 5,000 & 27 & IDR & 135,000 \\
\hline IDR 10,000 & 53 & IDR & 530,000 \\
\hline IDR 15,000 & 1 & IDR & 15,000 \\
\hline IDR 20,000 & 5 & IDR & 100,000 \\
\hline IDR 50,000 & 1 & IDR & 50,000 \\
\hline IDR 70,000 & 1 & IDR & 70,000 \\
\hline Total & 97 & IDR9 & $7,000,00$ \\
\hline
\end{tabular}


There are 6 people or 7\% of research respondents with a WTP value of IDR0 or not willing to pay. A total of 2 people or $2 \%$ of respondents are willing to pay IDR2,000 and the WTP value is IDR4,000. As many as 1 person or $1 \%$ of respondents are willing to pay IDR 3,000 for the preservation of community forests. Furthermore, respondents who are willing to pay IDR 5,000 are 27 people or $29 \%$ of the total number of research respondents, and the WTP value is IDR 135,000 . A total of 53 people or $57 \%$ of respondents are willing to pay IDR 10,000 for the preservation of community forests, and the WTP value is IDR 530,000, this is the largest amount. As many as 1 person or $1 \%$ of respondents are willing to pay with a WTP value of IDR 15,000 . A total of 5 people or $1 \%$ of respondents are willing to pay IDR 20,000 and the WTP value is IDR 100,000 . Then, the respondents who are willing to pay IDR 50,000 and IDR 70,000 for the preservation of community forests are 1 respondent each with a percentage value of $1 \%$ of the total number of research respondents.

\subsubsection{Estimating the average value of WTP}

The WTP of the community to preserve HR is quite varied, ranging from IDR0 to IDR70,000 per month. Based on the research conducted, the total value of WTP issued by respondents is IDR 907,000 per month with the average WTP of the community is IDR 9,351 per month or IDR $112,212.00$ per year, this value is the amount of money that is willing to be paid by the community. the community in this case as research respondents so that they can continue to enjoy the environmental services provided by community forests, and also for generations after them, namely their children and grandchildren.

\subsubsection{Sum the data}

To get the value of inheritance, the value of WTP per year is multiplied by the total population in Bantul Regency, which is 314,353 families [42], then the value of inheritance from community forests in Pajangan District is IDR 35,274,178,836 / year.

The results of research [38] show that the selected economic value of the Bukit Soeharto Grand Forest Park, East Kalimantan is IDR 3,753,200,039,362.83. This value is obtained by calculating the community's willingness to pay (WTP) with an average of IDR $8,796,000$ / year, with a population of 43,036 families. This value is much larger than the WTP value of the community forest in Pajangan District, this is because the average value of the WTP of the Bukit Soeharto Community Forest Park, East Kalimantan is greater.

\subsection{Total Economic Value of Community Forests in Pajangan District.}

Total Economic Value (NET) is the total amount of the sum of all quantification or estimated economic value of each benefit contained in the community forest of Pajangan District. As explained in the research results, the values calculated to get the total economic value (NET) are direct use value, indirect use value, option value, and non-use value. These values are the result of calculating the economic value of the products and services found in the community forest of Pajangan District (Table 8).

The Pajangan District community forest has products other than wood which are also available in the forest area whose economic value can be estimated using existing economic approaches $[43,44,45]$. The environmental services contained from forest resources, or the benefits derived from forest functions can also be estimated for their economic value. The economic value of community forest in Pajangan District is divided into four groups of values, namely: direct use value, indirect use value, option value and non-use value. The total economic value (TEV) of Pajangan District Community Forest is IDR 
$70,298,307,526 /$ year, this value is obtained based on the sum of the direct use value IDR $9,344,000,000 /$ year, indirect use value IDR 24,384,870,282/year, options IDR 1,295,258,408.00/year, and non-use value IDR 35,274,178,836/year (see Table 8). The direct use value which accounts for $13 \%$ of the total TEV of the community forest in Pajangan District is the value obtained from the value of logs of IDR 9,200,000,000/year and the value of firewood of IDR 144,000,000/year. Furthermore, the indirect use value contributes $35 \%$ of the total TEV of the community forest in Pajangan District, which is the value obtained from the carbon sink value of IDR 2,546,751,882/year and the spring value of IDR21,838,118,400/year. While the value of choice which contributes $2 \%$ is the value obtained from the calculation of the value of biodiversity, which is IDR $1,295,258,408 /$ year, and the last is the non-use value that contributes $50 \%$ of the TEV of the community forest of Pajangan District, which is the value obtained from the inheritance value of IDR 35,274,178,836/year.

Table 9. Total Economic Value (Net) of Community Forests in Pajangan District

\begin{tabular}{|l|c|}
\hline \multicolumn{1}{|c|}{ Benefit } & \multicolumn{1}{|c|}{$\begin{array}{c}\text { Economic Value } \\
\text { (per year) }\end{array}$} \\
\hline Use Value & \\
$\begin{array}{l}\text { Direct Use Value (DUV) } \\
\text { a. Log Wood Value } \\
\text { b. Firewood Value }\end{array}$ & IDR $9,200,000,000$ \\
Indirect Use Value (NDV) & IDR $144,000,000$ \\
$\begin{array}{l}\text { a. Carbon Absorbent Value } \\
\text { b. Spring Value }\end{array}$ & IDR $2,546,751,882$ \\
\hline $\begin{array}{l}\text { Option Value (OV) } \\
\text { Value of Biodiversity }\end{array}$ & IDR 21,838,118,400 \\
\hline $\begin{array}{l}\text { Non-Use Value } \\
\text { Inheritance Value (BV) }\end{array}$ & IDR 35,295,258,408 \\
\hline \multicolumn{1}{|c|}{ Total } & IDR 70,298,307,526 \\
\hline
\end{tabular}

\section{Conclusion}

The direct use value of the Pajangan District community forest is IDR 9,344,000,000/year. The indirect use value of the Pajangan District community forest is IDR $24,384,870,282 / y e a r$. The choice value of the community forest in Pajangan District is IDR $1,295,258,408 /$ year. The non-use value of the Pajangan District community forest is IDR 35,274,178.836/year. The Total Economic Value (TEV) of the Pajangan District community forest is IDR 70,298,307,526 /year. A critical stage is the incorporation of forest values into policy. Even when the importance of environmental elements is recognized, forest users and managers are generally hesitant to change their management practices. This could be due to the constant push to cut costs and enhance income. Forest regulation, confessions, and tax policy that are well designed can encourage forest users and management to account for non-market advantages in their own interests. As a result, regulatory oversight expenses may be reduced, resulting in a more efficient combination of market and non-market benefits. 


\section{References}

1. Pandit, B.H and Thapa, G.B. Who gains from non-timber forest products trading in the mountains of Nepal? In R. Uma Shaanker, Ankila J. Hiremath, Gladwin C. Joseph and Nitin D. Rai (eds.), Non-Timber Forest Products: Conservation, Management and Policy in the Tropics, Bangalore: Ashoka Trust for Research in Ecology and the Environment: 175- 187 (2009)

2. Warner, K., The vision and role of Community Forestry in sustainable development (1997)

3. Chaudhary S., Chettri N., Uddin K., Khatri T.B., Dhakal M., Bajracharya B., Ning W. Implications of land cover change on ecosystems services and people's dependency: A case study from the Koshi Tappu Wildlife Reserve, Nepal. Ecological Complexity 28: 200-211 (2016)

4. Qurniati R., Febryano I.G., Zulfiani D. How trust influence social capital to support collective action in agroforestry development? Biodiversitas 18(3): 1201-1206 (2017)

5. Widianingsih N.N., Theilade I., Pouliot M. 2016. Contribution of forest restoration to rural livelihoods and household income in Indonesia. Sustainability 8: 1-22 (2016)

6. Langat d., Maranga E.K., Aboud A.A., CheboiWo J.K. Role of forest resources to local livelihoods: The case of East Mau forest ecosystem, Kenya. International Journal of Forestry Research vol. 2016: 1-10 (2016)

7. Pokharel, B., and Nurse, M., Forest and peoples' livelihoods: Benefiting the poor from community forestry. Journal of Forestry and Livelihoods 4 (1), 19-29 (2004)

8. Banjade, M.R., Timsina, N.P., Neupane, H. R., Bhandari, K., Bhattrai, T., Rana, S. K., Transforming Agency and Structure for Facilitating Pro-Poor Governance in Community, Journal of Forest and Livelihood 5(1), 22-33 (2006)

9. Uprety, D.R., Community Forestry, rural livelihoods and conflict: A case study of CFUGs in Nepal. Ph.D. thesis, University of Natural Resources and Applied Life Sciences (BOKU), Vienna, Austria (2006)

10. Chetri, R.B., Pandey, T.R., User-group forestry in the far western region of Nepal: case studies from Baitadi and Achham. ICIMOD, Kathmandu, Nepal (1994)

11. Khanal, K.P., Economic Evaluation of Community Forestry in Nepal and its Equity Distribution Effect. M.Sc. Thesis Department of Economics and Natural Resources, Unit of Forestry .The Royal Veterinary and Agricultural University, Denmark. (2001)

12. Dahal, D.R., A review of FUG: a case studies from western Nepal. ICIMOD, Kathmandu, Nepal.

13. Undang-Undang Republik Indonesia Nomor 41 Tahun 1999 Tentang Kehutanan

14. [14] Keputusan Menteri Kehutanan Nomor 88/Ktps-II/2003 Tahun 2003 tentang Kriteria Potensi Hutan Pada Hutan Produksi yang Dapat Dilakukan Pemanfaatan Hutan Secara Lestari.

15. Susanto A., Triyono J. Cluster model of agroforestry land use to support food sustainability. Current Agriculture Research Journal 4(2): 143-147 (2016)

16. Kiptot E., Franzel S., Degrande A. Gender, agroforestry and food security in Africa. Current Opinion in Environmental Sustainability 6: 104-109 (2013)

17. Coulibaly J.Y., Chiputwa B., Nakelse T., Kundhlande G. Adoption of agroforestry and the impact on household food security among farmers in Malawi. Agricultural Systems 155: 52-69 (2017) 
18. Salampessy M.L., Febryano I.G., Zulfiani D. Principal agent in tree mortgage system on traditional agroforestry management in Moluccas Indonesia. IOP Conference Series: Earth and Environmental Science 285 (012013): 1-5 (2019)

19. Mbow c., Noordwijk M.V., luedeling e., neuFeldT h., minAng p.A., KoWero g. Agroforestry solutions to address food security and climate change challenges in Africa. Current Opinion in Environmental Sustainability 6: 61-67 (2014)

20. Noordwijk M.V., Bizard V., Wangpakapattanawong P., TATA H.L., Villamor G.B., Leimona B. Tree cover transitions and food security in Southeast Asia. Global Food Security 3: 200-208 (2014)

21. Jamnadass R., Place F., Torquebiau E.,Malézieux E., Iiyama M., Sileshi G.W. Agroforestry for food and nutritional security. Unasylva 64: 23-29 (2013)

22. [22] Vira B., Wildburger C., Mansourian S. Forests and Food: Addressing Hunger and Nutrition across Sustainable Landscapes.Open Book Publishers, Cambridge. 280 (2015)

23. Alao J.S., Shuaibu R.B. Agroforestry practices and concepts in sustainable land use systems in Nigeria. Journal of Horticulture and Forestry 5(10): 156-159 (2013)

24. El-Tantawi A.M., Badr A.M., Daura U.S. Benefits of agroforestry on smallholder farms in Jigawa State, Nigeria. Journal of Environmental Science, Toxicology and Food Technology 11: 31-38 (2017)

25. Oino P., Mugure A. Farmer-oriented factors that influence adoption of agroforestry practices in Kenya: Experiences from Nambale District, Busia County. International Journal of Science and Research 2(4): 442-449 (2013)

26. Mugiono, I., Penyusunan Database Hutan Rakyat di Pulau Jawa (Sebagai Prakondisi Implementasi Sistem Legalitas Kayu dan Rencana Proyek Karbon)". Workshop, Yogyakarta: Sahid-raya Hotel. (2009)

27. Hastari B., Yulianti R. Pemanfaatan dan nilai ekonomi hasil hutan bukan kayu di KPHL Kapuas-Kahayan [Utilization and economy value of non-timber forest product in KPHL Kapuas-Kahayan]. Jurnal Hutan Tropis 6(2) : 145-153 (in Indonesian) (2018)

28. Nurapriyanto I, Bahruni, Basuni S. Nilai ekonomi buah, kayu bakar dan air di Hutan Lindung Wosi Rendani (economic value of fruit, firewood and water in Wosi Rendani's forest.) Jurnal Faloak 2(2): 115-126 (2018)

29. Jahanifar K., Amirnejad H., Abedi Z., Vafaeinejad A. Estimation of the value of forest ecosystem services to develop conservational strategy management (strengths, weaknesses, opportunities and threats). Journal of Forest Science 63(7): 300-312 (2017)

30. Kadir Z.A. Penilaian Ekonomi Lanskap Agroforestri sebagai Jasa Lingkungan di Daerah Aliran Sungai Krueng Aceh [Agroforestry Landscape Economic Valuation as An Environmental Service in The Krueng Aceh River Basin]. Tesis. Sekolah Pascasarjana, Institut Pertanian Bogor, Bogor, 91 p. (in Indonesian). (2014)

31. Naidoo R. Economics and conservation in the tropics: A strategic dialogue. The role of economic valuation in the conservation of tropical nature. Conference Paper. Conservation Science Program, Gordon and Betty Moore Foundation, Resources for the future: 1-6 (2008)

32. Jilkova J., Hollander R., Kochmann L., Slavik J., Slavikova. Economic valuation of environmental resources and its use in local policy decision-making - A comparative Czech-German border study. Journal of Comparative Policy Analysis 1-13 (2010)

33. Tegenie y.A. Economic Valuation and Sustainable Natural Resources Management: Review Paper. Journal of Economics and Sustainable Development 6(7): 199-204 (2015) 
34. Kuncoro, M., Metode Riset untuk Bisnis dan Ekonomi. 4th ed. Jakarta: Erlangga (2013)

35. Sevilla, C. G., Research Methods. Quezon City: Rex Printing Company. (2007)

36. Wildayana, Valuasi Ekonomi Konversi Hutan Sekunder ke Usahatani Lahan Kering di Kecamatan Muara Enim Sumatera Selatan. Tesis. Bogor: Institut Pertanian Bogor (1999)

37. UMHR Wono Lestari Bantul, Unit Manajemen Hutan Rakyat Wono Lestari Bantul. (2017)

38. Yulian, E. N., Valuasi Sumberdaya Alam Taman Hutan Raya Bukit Soeharto Di Provinsi Kalimantan Timur. Tesis. Bogor: Institut Pertanian Bogor (2010)

39. Firdaus, H., Nilai Ekonomi Total dan Analisis Multistakeholder Hutan Rakyat Di Kecamatan Giriwoyo, Kabupaten Wonogiri, Jawa Tengah. Bogor: Institut Pertanian Bogor.(2013)

40. Thoha, A. S., Peluang Hutan Komunitas dan Perdagangan Karbon. [Online] Available at: www. latin.or.id/index.php-redd/44-peluang-hutan-komunitas-dan-perdagangankarbon.html [Accessed 23 October 2020], (2013)

41. Ariftia, R. I., Qurniati, A. R. \& Herwanti, S., Nilai Ekonomi Total Hutan Mangrove Desa Margasari Kecamatan Maringgai Kabupaten Lampung Timur. Journal of Suistainable Forest, Volume II (2014)

42. Disdukcapil Kabupaten Bantul, Data Kependudukan Berdasarkan Kartu Keluarga (KK), [Online] Available at: https://disdukcapil.bantulkab.go.id/data/list/23/24/41 data-kependudukan-dak2 [Accessed 2 January 2020], (2017)

43. Z. Rozaki, N. Rahmawati, O. Wijaya, A. F. Mubarok, M. Senge, and M. F. Kamarudin, A case study of agroforestry practices and challenges in Mt . Merapi risk and hazard prone area of Indonesia, Biodiversitas 22, 2511 (2021)

44. Z. Rozaki, N. Rahmawati, O. Wijaya, F. Safitri, M. Senge, and M. F. Kamarudin, Gender perspectives on agroforestry practices in Mt . Merapi hazards and risks prone area of Indonesia, Biodiversitas 22, 2980 (2021)

45. B. Winarno, Neoliberal Policy of Indonesia's Agricultural Revitalization, Jurnal Hubungan Internasional 5, 31 (2016) 